Jurnal Kesehatan

Volume 12, Nomor 3, Tahun 2021

ISSN 2086-7751 (Print), ISSN 2548-5695 (Online)

http://ejurnal.poltekkes-tjk.ac.id/index.php/JK

\title{
Efek Samping Terapi Antiretroviral dan Kepatuhan Berobat Penderita HIV/AIDS
}

\section{Side Effects of Antiretroviral Therapy and Medication Adherence among HIV/AIDS Patients}

\author{
Rico Januar Sitorus ${ }^{1}$, Novrikasari ${ }^{2}$, Rizma Adlia Syakurah ${ }^{3}$, Merry Natalia ${ }^{4}$ \\ ${ }^{1,2,3}$ Fakultas Kesehatan Masyarakat, Universitas Sriwijaya, Indonesia \\ ${ }^{4}$ Kantor Kesehatan Pelabuhan (KKP), Palembang, Indonesia
}

\section{ARTICLE INFO}

\section{Article history}

Received date

14 Oct 2021

Revised date

25 Oct 2021

23 Nov 2021

Accepted date

26 Nov 2021

Keywords:

Adherence;

Antiretrovirals;

HIV/AIDS;

Side-effects.

\section{Kata kunci:}

Kepatuhan;

Antiretrovirals;

HIV/AIDS;

Efek samping.

\author{
ABSTRACT/ ABSTRAK
}

Antiretroviral treatment side-effects and patient compliance with medical instructions continue to be a growing challenge for HIV/AIDS patients. Arv therapy has resulted in a substantial intervention that has been successful in preventing transmission and opportunistic infection. The main objective of this study was to analyze the association between side-effects of ARV therapy and medication adherence as well as another potential confounding such as opportunistic infection, family support, stress level, knowledge of ARV, marital status, and occupation. This study is a quantitative approach by using cross-sectional methods. A total of 244 respondents from 1.180 patients with confirmed HIV registered in the Care Support and Treatment (CST) service and Sriwijaya Community in the City of Palembang to respond to the survey. Non-random sampling was used to collect the samples. As the result, the majority of the respondents were male $(84,43 \%), \geq 30$ years old $(57,4 \%)$, and secondary school graduates $(52 \%)$. After adjusting with stress and opportunistic infection variable, a Multivariate regression analysis revealed a positive relationship between side effects and medication adherence (p-value of 0,041; 0,05), OR Adj 2,131 (1,190-4,988). PLHV who had adverse effects had a 2.131 times worse adherence rate than those who did not. In conclusion, medication adherence must be greatly improved in light of therapeutic side effects, stress levels, and opportunistic infection.
Tantangan utama yang dihadapi pasien yang menjalani pengobatan terapi antiretroviral adalah efek samping pengobatan dan kepatuhan dalam menjalankan pengobatan. Pengobatan dengan terapi ini dapat mengurangi transmisi penularan, dan mencegah infeksi oportunistik. Penelitian ini bertujuan menganalisis hubungan antara efek samping terapi arv dengan kepatuhan berobat serta mempertimbangkan potensial confounding yaitu infeksi oportunistik, dukungan keluarga, pengetahuan arv, status menikah, dan pekerjaan. Penelitian ini menggunakan pendekatan kuantitatif dengan desain potong lintang (cross-sectional). Populasi penelitian ini adalah seluruh orang dengan HIV/AIDS (ODHA) yan tercatat di layanan Care Support and Treatment (CST) dan Komunitas Sriwijaya Plus di Kota Palembang sebanyak 1.180 dengan besar sampel minimum 244 orang. Teknik pengambilan sampel dilakukan secara non-random yaitu purposive sampling. Hasil penelitian menunjukkan bahwa mayoritas responden berjenis kelamin laki-laki $(84,43 \%)$, berada pada usia $\geq 30$ tahun $(57,4 \%)$, memiliki tingkat pendidikan SMA sebesar 52\%. Pada analisis multivariat terbukti bahwa efek samping berhubungan secara signifikan terhadap kepatuhan menjalankan pengobatan dengan $p$-value $0,041<\alpha ; 0,05$ dengan nilai OR Adj 2,131 $(1,190-4,988)$ setelah dikontrol dengan variabel stres dan infeksi opportunistik. Ini menunjukkan bahwa ODHA yang mengalami efek samping memiliki kemungkinan 2,131 kali lebih besar untuk tidak patuh berobat arv dibandingkan dengan yang memiliki efek samping. Peningkatan kepatuhan berobat harus dilakukan secara komprehensif dengan mempertikan efek samping pengobatan, tingkat stres pasien dan adanya infeksi oportunistik.

Corresponding Author:

Rico Januar Sitorus

Fakultas Kesehatan Masyarakat, Universitas Sriwijaya, Indonesia

Email: rico_januar@fkm.unsri.ac.id 


\section{PENDAHULUAN}

Penularan human immunodeficincy virus (HIV) dapat terjadi pada berbagai populasi kunci dimasyarakat seperti kelompok penasun, dan kelompok Lelaki seks Lelaki (LSL). Secara global angka kematian di dunia akibat HIV mencapai 39 juta orang dan orang hidup dengan HIV sebanyak 36 juta orang. Infeksi human immunodeficiency virus (HIV) terus memberikan beban berat pada sistem perawatan kesehatan secara global. Selama dua dekade pertama epidemi berubah secara drastis dengan diperkenalkannya terapi antiretroviral (ARV). Orang yang hidup dengan HIV (ODHA) sekarang hidup lebih produktif selama mereka tetap mematuhi rejimen arv yang diresepkan (Frank, et al., 2019).

Penularan HIV/AIDS juga terjadi pada anak-anak. Secara global, 1,8 juta anak $<15$ tahun hidup dengan HIV (WHO, 2015). Proporsi orang dengan HIV/AIDS (ODHA) yang menerima terapi antiretroviral (ARV) seumur hidup pada orang dewasa sebesar $68 \%$ dan $53 \%$ pada anakanak, sedangkan ODHA pada ibu hamil yang menerima terapi antiretroviral sebesar $85 \%$. Terapi antiretroviral pada ibu hamil dapat mencegah penularan ke bayinya (WHO, 2021). Terapi antiretroviral (ARV) sejak dini pada ODHA juga direkomendasikan Organisasi Kesehatan Dunia (WHO) untuk menurunkan risiko menularkan, mencegah infeksi oportunistik, menurunkan kasus baru dan mencegah kematian dini (Montaner, et al., 2014; WHO, 2015).

Terapi antiretroviral terbukti membawa penurunan yang substansial pada tingkat kematian akibat infeksi HIV, mengubahnya dari penyakit yang cepat mematikan menjadi kondisi kronis yang dapat ditangani, kompatibel dengan kelangsungan hidup yang panjang. UNAIDS membuat suatu program aspirasi $90-90-90$ yang bertujuan untuk mendiagnosis $90 \%$ orang yang hidup secara global, memberikan pengobatan kepada $90 \%$ orang yang didiagnosis, dan mencapai penekanan virus pada $90 \%$ orang yang memakai pengobatan pada tahun 2020 (Gaolathe, et al., 2016; UNAIDS, 2020). Terapi antiretroviral harus dilanjutkan seumur hidup dan kepatuhan diperlukan. Kepatuhan yang tinggi $>95 \%$ dalam meminum obat arv diperlukan untuk menurunkan viral load. Penatalaksanaan HIV/AIDS tidak hanya difokuskan pada masalah fisik, tetapi juga pada efek psikososial. Perkembangan obat antiretroviral telah secara signifikan mengubah persepsi tentang penyakit HIV/AIDS dari penyakit yang sangat berbahaya menjadi penyakit kronis. Jika ditangani dengan baik, sehingga dapat mengurangi mortalitas, morbiditas dan meningkatkan kualitas hidup (Oguntibeju, 2012).

Keberhasilan pengobatan sangat bergantung pada kemampuan pasien untuk mengakses pengobatan dan kepatuhan yang ketat pada rejimen obat yang diperlukan. Pasien harus minum obat dengan dosis yang tepat, pada waktu yang sama setiap hari agar pengobatan menjadi efektif (Peltzer \& Pengpid, 2013). Salah satu tantangan utama yang dihadapi pasien dengan terapi antiretroviral adalah kejadian reaksi obat yang merugikan dan berhubungan dengan kepatuhan pasien yang buruk. Dampak serius dari penghentian pengobatan adalah munculnya resistensi obat, membuat intervensi terapeutik di masa depan tidak efektif (Olem, et al., 2014).

ODHA yang menjalankan pengobatan ini memiliki tantangan besar terhadap efek samping yang akan diterima. Efek samping utama dari terapi antiretroviral seperti mual, diare, muntah, konstipasi, sakit kepala, masalah penglihatan, insomnia, hilangnya fungsi penciuman, anemia, kecemasan, kebingungan, depresi, mimpi buruk, dan delusi (Tadesse, et al., 2014).

Beban psikososial yang terinfeksi HIV/AIDS lebih besar daripada beban fisiknya. Beban psikososial akan sangat mempengaruhi kelangsungan hidup mereka, dapat menyebabkan masalah kesehatan emosional dan mental yang dapat menyebabkan gangguan mental emosional dan kepatuhan pengobatan yang buruk. Untuk mengurangi efek samping terapi antiretroviral, pasien harus patuh dalam melakukan pengobatan. Keberhasilan pengobatan harus didukung oleh kepatuhan minum obat secara teratur minum obat sesuai dengan anjuran dokter sehingga dapat mencegah kegagalan pengobatan dan risiko resistensi obat. Tantangan yang besar dalam menjalankan pengobatan yang dihadapi terutama pada saat memulai pengobatan. Memaksimalkan kepatuhan pengobatan HIV sangat penting dalam upaya untuk mengoptimalkan kesehatan dan mencegah penularan HIV lebih lanjut.

Tujuan dari penelitian ini adalah untuk mengetahui hubungan efek samping terapi antiretroviral dengan kepatuhan menjalankan pengobatan.

\section{METODE}

Penelitian ini menggunakan pendekatan kuantitatif dengan desain cross-sectional. Penelitian ini menganalisis hubungan antara efeksamping terapi ARV dengan kepatuhan 
minum obat serta mempertimbangkan potensial confounding yaitu infeksi opportunistik, dukungan keluarga, pengetahuan ARV, status menikah, dan pekerjaan. Populasi penelitian ini adalah seluruh ODHA yan tercatat di layanan Care Support and Treatment (CST) dan Komunitas Sriwijaya Plus di Kota Palembang sebanyak 1.180.

Besar sampel minimal dalam penelitian ini dihitung berdasarkan rumus Lemeshow, et al (1997) dua proporsi populasi dengan jumah sampel minimum 222 orang. Untuk menghindari adanya missing data, sampel ditambah $10 \%$, sehingga jumlah sampel yang akan diambil dalam penelitian ini sebanyak 244 orang.

Teknik pengambilan sampel dilakukan secara nonrandom yaitu purposive sampling. Untuk mengukur variabel independen utama yaitu efek samping ditanyakan melalui kuisioner terstruktur yang disudah dikembangkan oleh para Peneliti. Jenis efek samping yang dialami ODHA juga divalidasi dengan melihat rekam medis responden yang ada di fasilitas kesehatan tempat menerima layanan ARV. Untuk mengukur variabel dependen yaitu kepatuhan berobat dengan bertanya menggunakan kuisiner terstruktur yang sudah dikembangkan oleh tim peneliti. Kepatuhan berobat dibagi menjadi 2 kategori yaitu Patuh dan tidak patuh. Seorang responden dikatakan patuh apabila minum ARV $\geq 95 \%$ (lupa minum obat $<3$ dosis dalam 30 hari) dan tidak patuh apabila minum ARV $<95 \%$.

Data penelitian yang sudah dikumpulkan selanjutnya dianalisis secara statistik dengan tahapan mulai dari analisis secara univariat yang bertujuan menggambarkan karakteristik responden, selanjutnya dianalisis secara bivariat dengan tujuan untuk mengetahui hubungan variabel independen utama (efek samping terapi arv) dengan kepatuhan pengobatan dengan menggunakan uji chi-square. Untuk mengetahui apakah hubungan variabel independent utama (efek samping terapi ARV) dengan kepatuhan pengobatan dipengaruhi variabel perancu (confounding) dilakukan analisis multivariat dengan menggunkan uji regresi logistik ganda.Penelitian ini telah melalui kaji etik dan dinyatakan layak etik untuk dilaksanakan di Fakultas Kesehatan Masyarakat Universitas Sriwijaya dengan Nomor 149/UN9.FKM/TU.KKE/2021.

\section{HASIL}

Tabel 1. Karakteristik Responden

\begin{tabular}{|c|c|c|}
\hline Variabel & $\mathbf{f}$ & $\%$ \\
\hline \multicolumn{3}{|l|}{ Umur } \\
\hline$<30$ tahun & 104 & 42,6 \\
\hline$\geq 30$ tahun & 140 & 57,4 \\
\hline \multicolumn{3}{|l|}{ Jenis Kelamin } \\
\hline Laki-laki & 206 & 84,43 \\
\hline Perempuan & 38 & 15,57 \\
\hline \multicolumn{3}{|l|}{ Tingkat Pendidikan } \\
\hline Tidak sekolah & 1 & 0,4 \\
\hline Tamat SD & 15 & 6,1 \\
\hline Tamat SMP & 13 & 5,3 \\
\hline Tamat SMA & 127 & 52,0 \\
\hline Tanat D3 & 23 & 9,4 \\
\hline Tamat S-1 & 62 & 25,4 \\
\hline Tamat S-2 & 2 & 1,2 \\
\hline \multicolumn{3}{|l|}{ Pekerjaan } \\
\hline PNS/BUMN & 15 & 6,1 \\
\hline Pegawai swasta & 81 & 33,2 \\
\hline Wiraswasta & 70 & 28,7 \\
\hline Buruh & 28 & 11,5 \\
\hline Pelajar/Mahasiswa & 9 & 3,7 \\
\hline Ibu Rumah Tangga & 16 & 6,6 \\
\hline Lainnya & 7 & 2,9 \\
\hline Tidak berkerja & 18 & 7,4 \\
\hline \multicolumn{3}{|l|}{ Status Pernikahan } \\
\hline Menikah & 72 & 29,5 \\
\hline Tidak menikah & 157 & 64,3 \\
\hline Janda & 5 & 2,0 \\
\hline Duda & 10 & 4,1 \\
\hline \multicolumn{3}{|l|}{ Lama Pengobatan } \\
\hline$<1$ tahun & 31 & 12,7 \\
\hline$\geq 1$ tahun & 213 & 87,3 \\
\hline \multicolumn{3}{|l|}{ Cara Penularan } \\
\hline Hubungan Seksual & 206 & 84,4 \\
\hline Transfusi Darah & 9 & 3,7 \\
\hline Penggunaan Jarum Suntik & 23 & 9,4 \\
\hline Transplantasi Organ & 1 & 0,4 \\
\hline Ibu ke Anak & 5 & 2,0 \\
\hline \multicolumn{3}{|l|}{ Status Hubungan Seksual } \\
\hline LSL & 142 & 58,2 \\
\hline Bukan LSL & 102 & 41,8 \\
\hline \multicolumn{3}{|l|}{ Infeksi Oportunistik } \\
\hline Ada & 52 & 21,3 \\
\hline Tidak Ada & 192 & 78,7 \\
\hline \multicolumn{3}{|l|}{ Jenis Infeksi Oportunistik } \\
\hline Tuberculosis & 23 & 9,4 \\
\hline Meningitis Kritokokus & 4 & 1,7 \\
\hline Diare & 10 & 4,1 \\
\hline Sitomegalo & 1 & 0,4 \\
\hline Kanker terkait HIV & 0 & 0 \\
\hline Infeksi CMV & 2 & 0,8 \\
\hline Korioretinitis Toksoplasmosis & 1 & 0,4 \\
\hline Lainnya & 19 & 7,8 \\
\hline \multicolumn{3}{|l|}{ Efek Samping Obat } \\
\hline Ada & 172 & 70,5 \\
\hline Tidak Ada & 72 & 29,5 \\
\hline \multicolumn{3}{|l|}{ Kepatuhan berobat } \\
\hline Tidak patuh & 133 & 54,5 \\
\hline Patuh & 111 & 45,5 \\
\hline
\end{tabular}


Hasil penelitian menunjukkan bahwa mayoritas responden berjenis kelamin laki-laki $(84,43 \%)$. Berdasarkan kategori usia, mayoritas responden berada pada usia $\geq 30$ tahun tahun (57,4\%). Responden memiliki tingkat pendidikan yang beragam mulai tidak sekolah sampai tamat perguruan tinggi. Dari level tingkat pendidikan, responden dengan tamat SMA dan Perguruan tinggi cukup tinggi. Responden dengan tamat SMA sebesar 52\%, sedangkan responden yang tamat perguruan tinggi sebesar $36 \%$. Hal ini menandakan bahwa orang dengan HIV/AIDS pada penelitian mempunyai tingkat pendidikan yang tinggi. Berdasarkan jenis pekerjaan, responden memiliki jenis pekerjaan yang beragam. Jenis pekerjaa yang paling banyak adalah pegawai swasta $(33,2 \%)$. Berdasarkan status pernikahan, mayoritas responden menikah $(64,3 \%)$.

\section{Tabel 2. Hubungan antara Variabel Dependen dan Variabel Independen}

\begin{tabular}{|c|c|c|c|c|c|c|}
\hline \multirow{3}{*}{ Variabel } & \multicolumn{4}{|c|}{ Kepatuhan Berobat } & \multirow{3}{*}{$p$-value } & \multirow{3}{*}{ Nilai OR $(95 \% \mathrm{CI})$} \\
\hline & \multicolumn{2}{|c|}{ Tidak patuh } & \multicolumn{2}{|c|}{ Patuh } & & \\
\hline & $\mathbf{n}$ & $\%$ & $\mathbf{n}$ & $\%$ & & \\
\hline \multicolumn{7}{|l|}{ Efek samping obat } \\
\hline Ada & 49 & 28,5 & 123 & 71,5 & 0,006 & $2,564(1,280-5,137)$ \\
\hline Tidak ada & 8 & 11,1 & 64 & 88,9 & & \\
\hline Stigma sosial & & & & & 0,085 & $1,867(0,940-3,707)$ \\
\hline Tinggi & 49 & 26,2 & 138 & 73,8 & & \\
\hline Rendah & 8 & 14,0 & 49 & 86,0 & & \\
\hline Dukungan keluarga & & & & & 0,759 & $1,173(0,623-2,209)$ \\
\hline Rendah & 48 & 24,0 & 152 & 76,0 & & \\
\hline Tinggi & 9 & 20,5 & 35 & 79,5 & & \\
\hline Selfefficacy & & & & & 0,015 & $1,850(1,142-2,298)$ \\
\hline Rendah & 37 & 30,3 & 85 & 69,7 & & \\
\hline Tinggi & 20 & 16,4 & 102 & 83,6 & & \\
\hline Stres & & & & & 0,000 & $2,582(1,671-3,991)$ \\
\hline Berat & 18 & 48,6 & 19 & 51,4 & & \\
\hline Ringan & 39 & 18,8 & 168 & 81,2 & & \\
\hline \multicolumn{7}{|l|}{ Infeksi opportunistik } \\
\hline Ada & 19 & 36,5 & 33 & 63,5 & 0,019 & $1,846(1,168-2,917)$ \\
\hline Tidak ada & 38 & 19,8 & 154 & 80,2 & & \\
\hline \multicolumn{7}{|l|}{ Lama berobat } \\
\hline$<1$ tahun & 6 & 19,4 & 25 & 80,6 & 0,736 & $0,808(0,379-1,724)$ \\
\hline$\geq 1$ tahun & 51 & 23,9 & 162 & 76,1 & & \\
\hline
\end{tabular}

Pada analisis bivariat, hasil penelitian ini menunjukkan bahwa efek samping, self-efficacy, stres dan infeksi opportunistik secara signifikan berhubungan kepatuhan berobat. Faktor efek samping mempengaruhi kepatuhan ODHA dalam menjalankan pengobatan dengan p-value $0,006<$ $; 0,05$ dengan nilai odds ratio $2,564 \quad(1,280-$ $5,137)$. Hal ini menunjukkan bahwa ODHA yang mengalami efek samping memiliki kemungkinan 2,564 kali lebih besar untuk tidak patuh berobat arv dibandingkan dengan yang tidak memiliki efek samping. Faktor self-efficacy berhubungan secara signifikan terhadap kepatuhan berobat dengan $p$-value $0,015<\alpha ; 0,05$ dengan nilai odds ratio $1,850(1,142-2,298)$. Hal ini menunjukkan bahwa ODHA dengan self-efficacy rendah memiliki kemungkinan 1,850 kali lebih besar untuk tidak patuh berobat ARV dibandingkan dengan yang memiliki self-efficay tinggi. Faktor stres berhubungan secara signifikan terhadap kepatuhan berobat dengan $p$-value $0,000<\alpha ; 0,05$ dengan nilai odds ratio 2,582 (1,671-3,991). Hal ini menunjukkan bahwa ODHA dengan stres berat memiliki kemungkinan 2,582 kali lebih besar untuk tidak patuh berobat ARV dibandingkan dengan ODHA dengan stres ringan.

Faktor infeksi oportunistik mempengaruhi kepatuhan ODHA dalam menjalankan pengobatan dengan $p$-value $0,019<\alpha ; 0,05$ dengan nilai odds ratio $1,846(1,168-2,917)$. Hal ini menunjukkan bahwa ODHA yang memiliki infeksi oportunistik memiliki kemungkinan 1,846 kali lebih besar untuk tidak patuh berobat arv dibandingkan dengan yang tidak memiliki infeksi oportunistik. Hasil penelitian juga menunjukkan bahwa stigma sosial, dukungan keluarga, dan lama berobat tidak berhubungan secara signifikan terhadap kepatuhan dalam menjalankan pengobatan. 
Tabel 3. Model Akhir Regresi Logistik dengan Model Faktor Risiko

\begin{tabular}{lcccccc}
\hline \multirow{2}{*}{ Variabel } & \multirow{2}{*}{ B } & S.E. & Sig. & Exp $(B)$ & \multicolumn{3}{c}{ 95\% CI for $\operatorname{EXP}(\mathbf{B})$} \\
\hline Efek Samping Obat & 0,756 & 0,358 & 0,041 & 2,131 & 1,190 & 4,988 \\
Stres & 1,131 & 0,391 & 0,004 & 3,099 & 1,439 & 6,671 \\
Infeksi Oportunistik & 0,627 & 0,358 & 0,080 & 1,871 & 0,928 & 3,773 \\
Constant & $-2,884$ & 0,930 & 0,002 & 0,056 & & \\
\hline
\end{tabular}

Pada analisis multivariat terbukti bahwa efek samping berhubungan secara signifikan terhadap kepatuhan menjalankan pengobatan dengan $p$-value $0,041<\alpha ; 0,05$ dengan nilai odds ratio 2,131 (1,190-4,988) setelah dikontrol dengan variabel stress dan infeksi oportunistik. Ini menunjukkan bahwa ODHA yang mengalami efek samping memiliki kemungkinan 2,131 kali lebih besar untuk tidak patuh berobat ARV dibandingkan dengan yang memiliki efek samping.

\section{PEMBAHASAN}

Hasil penelitian ini menunjukkan bahwa ODHA yang menjalani terapi antiretroviral lebih banyak mendapatkan efek samping akibat pengobatan dibandingkan dengan yang tidak mengalami efek samping. Hal ini sejalan dengan kepatuhan dalam menjalankan terapi antiretroviral, dimana mayoritas ODHA tidak patuh dalam menjalankan pengobatan. Hasil penelitian membuktikan bahwa ada hubungan antara efek samping terapi antiretroviral dengan kepatuhan berobat. ODHA yang mengalami efek samping memiliki kemungkinan 2,131 kali lebih besar untuk tidak patuh berobat ARV dibandingkan dengan yang memiliki efek samping. Penelitian ini sejalan dengan penelitian yang dilakukan oleh Dima, et al. di Rumania yang menemukan bahwa efek samping terapi antiretroviral, menjadi penghalang utama kepatuhan terapi (Dima, et al., 2013).

Kepatuhan terhadap terapi arv dapat meningkatkan indeks massa tubuh, mengurangi viral load ke tingkat tidak terdeteksi, meningkatkan jumlah CD4, dan dapat mengurangi efek samping akibat menjalankan pengobatan (Olowookere, et al., 2016). Efek samping yang dialami responden pada penelitian ini adalah mual, muntah, dan pusing. Menurut CDC (2020), obat HIV dapat menyebabkan efek samping pada beberapa orang, tetapi tidak semua orang mengalami efek samping. Efek samping yang paling umum adalah mual dan muntah, diare, kesulitan tidur, mulut kering, sakit kepala, ruam, pusing, kelelahan, dan rasa sakit (Centers for Disease Control and Prevention, 2021). Efek samping secara signifikan berhubungan dengan kepatuhan terhadap terapi antiretroviral. Kepatuhan terapi antiretroviral sangat penting untuk mencapai penekanan virus dan menghindari resistansi obat karena terapi antiretroviral adalah pengobatan seumur hidup. Kepatuhan yang optimal dapat mencegah penularan HIV kepada orang lain yang berisiko terhadap infeksi dan kelangsungan hidup (Zhang, et al., 2016).

Penelitian sebelumnya

telah mengidentifikasi faktor-faktor yang menjadi hambatan utama untuk kepatuhan arv yang optimal yaitu penggunaan narkoba, gejala depresi, bepergian, kesibukan, efek samping terkait ARV, kegagalan untuk menggunakan isi ulang obat ARV, stigma/diskriminasi, dan kurangnya dukungan keluarga. Ketidakpatuhan terhadap terapi pada ODHA dapat mengakibatkan resistensi obat ARVatau kegagalan pengobatan (Geng, et al., 2016; Ndiaye, et al., 2013). Pada penelitian ini, stres, dan infeksi oportunistik (komorbiditas) menjadi variabel confounding. Hal ini menunjukkan bahwa kedua variabel tersebut mempengaruhi kepatuhan berobat. Penelitian ini sejalan dengan penelitian Najjar, et al., dimana hasil penelitiannya mengungkapkan bahwa memiliki riwayat penyakit kronik mempengaruhi untuk tidak menjalankan pengobatan secara teratur. Kepatuhan pasien terhadap pengobatan dapat dipengaruhi oleh banyak faktor termasuk pola komunikasi antara pasien dengan profesional kesehatan, keyakinan, sumber daya pasien termasuk keuangan, psikologis, dukungan sosial, kondisi komorbiditas dan pengetahuan pasien (Najjar, et al., 2015; Pellowski \& Kalichman, 2016).

Individu yang hidup dengan HIV di komunitas yang dilanda kemiskinan menghadapi tantangan dalam mengakses pengobatan karena ketidakamanan ekonomi, termasuk kurangnya keuangan untuk transportasi ke fasilitas kesehatan untuk berobat, makanan yang tidak memadai untuk mendukung konsumsi obat (Nabukeera-Barungi, et al., 2015). Orang yang terinfeksi human immunodeficiency virus (HIV) juga berisiko terhadap infeksi lain seperti hepatitis B dan hepatitis C. Prevalensi ODHA 
yang mengalami coinfeksi hepatitis B di populasi sebesar 4,4\%, sedangkan Hepatitis C sebesar 19,4\% (Ionita, et al., 2017; Petty, et al., 2014).

Hasil penelitian ini mengungkapkan proporsi yang mengalami infeksi oportunistik $(21,3 \%)$ lebih rendah bila dibandingkan dengan yang tidak mengalami. Jenis komorbiditas yang dialami penderita HIV/AIDS pada dalam penelitian adalah TB paru $(9,4 \%)$, diare $(4,1 \%)$, dan lain-lain $(7,8 \%)$.

Pengetahuan pasien yang memadai tentang pengobatan penting untuk perilaku penggunaan obat yang tepat dan kepatuhan pasien. Untuk meningkatkan kepatuhan terapi perlu didukung oleh self-efficacy yang baik. Self-efficacy adalah faktor psikososial yang dapat dimodifikasi terkait dengan keyakinan individu dalam kemampuan mereka untuk berhasil menyelesaikan tindakan dan telah terbukti terkait secara positif dengan kinerja. Self-efficacy yang baik dapat meningkatkan performa diri seseorang sehingga dia merasa positif dan ingin memperbaiki diri sendiri (Themanson \& Rosen, 2015).

\section{DAFTAR PUSTAKA}

Centers for Disease Control and Prevention. (2021). HIV Treatment. https://www.cdc.gov/hiv/basics/livingwith hiv/treatment.html. (n.d.).

Dima, A. L., Schweitzer, A.-M., Diaconiţă, R., Remor, E., \& Wanless, R. S. (2013). Adherence to ARV medication in Romanian young adults: Self-reported behaviour and psychological barriers. Psychology, Health \& Medicine, 18(3), 343-354. https://doi.org/10.1080/13548506.2012.722648

Gaolathe, T., Wirth, K. E., Holme, M. P., Makhema, J., Moyo, S., Chakalisa, U., Yankinda, E. K., Lei, Q., Mmalane, M., \& Novitsky, V. (2016). Botswana's progress toward achieving the 2020 UNAIDS 9090-90 antiretroviral therapy and virological suppression goals: a population-based survey. The Lancet HIV, 3(5), e221-e230.

Frank, T. D., Carter, A., Jahagirdar, D., Biehl, M. H., Douwes-Schultz, D., Larson, S. L., ... \& Hosseinzadeh, M. (2019). Global, regional, and national incidence, prevalence, and mortality of HIV, 19802017, and forecasts to 2030, for 195 countries and territories: a systematic analysis for the Global Burden of Diseases, Injuries, and Risk Factors Study 2017. The lancet HIV, 6(12), e831-e859.

\section{SIMPULAN}

Hasil studi ini membuktikan bahwa efek samping terapi arv berhubungan secara signifikan terhadap kepatuhan menjalankan pengobatan. ODHA yang mengalami efek samping memiliki kemungkinan 2,131 kali lebih besar untuk tidak patuh terapi arv dibandingkan dengan yang memiliki efek samping setelah dikontrol dengan variabel infeksi oportunistik, dan stres. Oleh karena itu, perlu diberikan pemahaman bahwa setiap jenis terapi pengobatan yang dijalankan oleh ODHA memiliki efek samping masingmasing, memantau ODHA secara terus menerus dan membuat manajemen efek samping terapi. Untuk itu, dengan menjalankan pengobatan yang teratur akan dapat mengurangi risiko komplikasi atau penyakit lain dengan didukung pasangan bagi yang sudah menikah dan tempat pekerjaan memberikan ijin berobat ketika menjalankan pengobatan pada saat jam kerja.

Geng, E. H., Odeny, T. A., Lyamuya, R., Nakiwogga-Muwanga, A., Diero, L., Bwana, M., Braitstein, P., Somi, G., Kambugu, A., \& Bukusi, E. (2016). Retention in care and patient-reported reasons for undocumented transfer or stopping care among HIV-infected patients on antiretroviral therapy in Eastern Africa: application of a sampling-based approach. Clinical Infectious Diseases, 62(7), 935-944.

Ionita, G., Malviya, A., Rajbhandari, R., Schluter, W. W., Sharma, G., Kakchapati, S., Rijal, S., \& Dixit, S. (2017). Seroprevalence of hepatitis B virus and hepatitis $\mathrm{C}$ virus co-infection among people living with HIV/AIDS visiting antiretroviral therapy centres in Nepal: a first nationally representative study. International Journal of Infectious Diseases, 60, 64-69. https://doi.org/https://doi.org/10.1016/j.ijid .2017.04.011.

Montaner, J. S. G., Lima, V. D., Harrigan, P. R., Lourenço, L., Yip, B., Nosyk, B., Wood, E., Kerr, T., Shannon, K., \& Moore, D. (2014). Expansion of HAART coverage is associated with sustained decreases in HIV/AIDS morbidity, mortality and HIV transmission: the "HIV Treatment as Prevention" experience in a Canadian 
setting. PloS One, 9(2), e87872.

Nabukeera-Barungi, N., Elyanu, P., Asire, B., Katureebe, C., Lukabwe, I., Namusoke, E., Musinguzi, J., Atuyambe, L., \& Tumwesigye, N. (2015). Adherence to antiretroviral therapy and retention in care for adolescents living with HIV from 10 districts in Uganda. BMC Infectious Diseases, 15(1), 1-10.

Najjar, A., Amro, Y., Kitaneh, I., Abu-Sharar, S., Sawalha, M., Jamous, A., Qiq, M., Makharzeh, E., Subb Laban, B., Amro, W., \& Amro, A. (2015). Knowledge and Adherence to Medications among Palestinian Geriatrics Living with Chronic Diseases in the West Bank and East Jerusalem. PloS One, 10(6), e0129240e0129240.

https://doi.org/10.1371/journal.pone.0129240

Ndiaye, M., Nyasulu, P., Nguyen, H., Lowenthal, E. D., Gross, R., Mills, E. J., \& Nachega, J. B. (2013). Risk factors for suboptimal antiretroviral therapy adherence in HIVinfected adolescents in Gaborone, Botswana: a pilot cross-sectional study. Patient Preference and Adherence, 7, 891.

Oguntibeju, O. O. (2012). Quality of life of people living with HIV and AIDS and antiretroviral therapy. Hiv/Aids (Auckland, $N Z), 4,117$.

Olem, D., Sharp, K. M., Taylor, J. M., \& Johnson, M. O. (2014). Overcoming barriers to HIV treatment adherence: A brief cognitive behavioral intervention for HIV-positive adults on antiretroviral treatment. Cognitive and Behavioral Practice, 21(2), 206-223.

Olowookere, S. A., Fatiregun, A. A., Ladipo, M. M. A., Abioye-Kuteyi, E. A., \& Adewole, I. F. (2016). Effects of adherence to antiretroviral therapy on body mass index, immunological and virological status of Nigerians living with HIV/AIDS. Alexandria Journal of Medicine, 52(1), 51-54. https://doi.org/https://doi.org/10.1016/j.aj me.2015.03.001.

Pellowski, J. A., \& Kalichman, S. C. (2016). Health behavior predictors of medication adherence among low health literacy people living with HIV/AIDS. Journal of Health Psychology, 21(9), 1981-1991. https://doi.org/10.1177/1359105315569617.

Peltzer, K., \& Pengpid, S. (2013). Socioeconomic factors in adherence to HIV therapy in low-and middle-income countries. Journal of Health, Population, and Nutrition, 31(2), 150.

Petty, L. A., Steinbeck, J. L., Pursell, K., \& Jensen, D. M. (2014). Human immunodeficiency virus and coinfection with hepatitis B and C. Infectious Disease Clinics, 28(3), 477-499.

Tadesse, W. T., Mekonnen, A. B., Tesfaye, W. H., \& Tadesse, Y. T. (2014). Self-reported adverse drug reactions and their influence on highly active antiretroviral therapy in HIV infected patients: a cross sectional study. BMC Pharmacology and Toxicology, 15(1), 1-9.

Themanson, J. R., \& Rosen, P. J. (2015). Examining the relationships between selfefficacy, task-relevant attentional control, and task performance: Evidence from event-related brain potentials. British Journal of Psychology, 106(2), 253-271. https://doi.org/https://doi.org/10.1111/bjop .12091.

UNAIDS. (2020). HIV Prevention 2020 Road Map.

http://www.unaids.org/sites/default/files/m edia_asset/hiv-prevention-2020-roadmap_en.pdf.

WHO. (2015). Guideline on when to start antiretroviral therapy and on pre-exposure prophylaxis for HIV. World Health Organization.

WHO. (2015). Fact sheet to the WHO consolidated guidelines on HIV testing services. World Health Organization.

WHO. (2021). HIV-AIDS. https://www.who.int/news-room/factsheets/detail/hiv-aids. (n.d.). Geneva.

Zhang, L., Li, X., Lin, Z., Jacques-Tiura, A. J., Xu, J., Zhou, Y., Qiao, S., Shen, Z., \& Stanton, B. (2016). Side effects, adherence self-efficacy, and adherence to antiretroviral treatment: a mediation analysis in a Chinese sample. AIDS Care, 28(7), 919-926. https://doi.org/10.1080/09540121.2015.11 24984. 